UDC 633.15:631.53.027:631.811

DOI:10.37128/2707-5826-2021-4-19

\section{INFLUENCE OF TECHNOLOGICAL METHODS OF GROWING ON THE LEAF SURFACE OF CORN}

SHEVCHENKO NATALIA, Candidate of Agricultural Sciences, senior teacher YAKOVETS LYUDMILA, Candidate of Agricultural Sciences, senior teacher, Vinnytsia National Agrarian University

The article presents the studies results of the foliar fertilization influence with microfertilizers and growth stimulants on the formation of the leaf surface area of corn hybrids, as the main component of photosynthetic potential of plants and their productivity in general.

One of the modern directions of increasing the yield and quality of crop products is the introduction of energy-saving technologies in agricultural production with the use of plant growth regulators and microfertilizers.

Their use for pre-sowing seed treatment provides intensive plant growth and development, high field germination, and spraying plants during the growing season promotes plant growth and development, increasing their resistance to adverse weather conditions, diseases, increasing yields. As a result, growth regulators and microfertilizers are increasingly becoming an integral part of intensive crop technologies. In addition, ensuring the productivity of plants and the optimal leaf surface area can be achieved not only by using a single growth stimulant or microfertilizer, but also their complex. Therefore, it is important to study the use of a complex of plant growth stimulants and microfertilizers, which, in turn, will ensure the realization of the biological potential of corn plants, and reduce costs per unit of output.

According to the program of our research, we studied the influence of microfertilizers and growth stimulants on the growth, development and formation of the assimilation surface of corn hybrids of different maturity groups. According to the research results, the highest leaf surface area was recorded in the medium-ripe hybrid Monica $350 \mathrm{MW}, 42,74$ thousand $\mathrm{m}^{2}$ / ha using foliar fertilization in the phase of 5-9 leaves with a complex of microfertilizers Nanomix-corn and growth stimulant Emistim S. Area leaf surface in the middle-early hybrid yield of 37,96 thousand $\mathrm{m}^{2} / \mathrm{ha}$, was also recorded for the use of this complex. Also, the use of only microfertilizers Nanomix-corn, led to an increase in leaf area for all studied hybrids.

Key words: corn, hybrid, leaf surface, microfertilizer, biostimulants.

Table 2. Lit. 7.

Introduction. Corn is the most important crop in the world in terms of distribution, versatility and energy value. In terms of crop area and grain production, it ranks second in the world. In the Vinnytsia region, corn is one of the traditional crops in the production of feed grain and is sown annually on an area of about 400 thousand hectares. The reason for the insufficient realization of the biological potential of the culture is the low validity of the adaptability of hybrids of differentmaturing hybrids of corn ripeness to certain conditions and cultivation technology [1].

Reserves for increasing corn productivity include the development and implementation of modern intensive and adaptive technologies for growing crops, which provide optimization of plant growth and development conditions based on biological and ecological control over the state at the main stages of organogenesis. 
The introduction of modern corn hybrids has necessitated further improvement of cultivation technology, taking into account the more efficient use of bioclimatic potential of soil and climatic conditions of the zone and the genetic potential of highyielding hybrids $[2,3]$.

Increasing the grain yield of corn in modern conditions is impossible without the use of scientifically sound technologies for its cultivation. The correct choice of hybrid taking into account the length of the growing season and the use of growth stimulants and foliar fertilization with micronutrients are determinants of high and stable yields of this crop. Therefore, our study is quite relevant.

Analysis of recent research and publications. The results of research by scientific institutions show that the reduction of the assimilating surface leads to a decrease in plant productivity. In this case, the most favorable conditions for the formation of the crop of the main cultivated plants are created when the total area of leaves is about 3-4 times larger than the area of land occupied by plants $[4,5]$.

According to recent studies, the formation of optimal plant productivity, including leaf surface can be achieved not by a single phytohormone or biologically active compound, but by a complex, applying them simultaneously or sequentially under optimal growing conditions. Therefore, one of the most important tasks of crop production is the development of the most rational schemes for the use of biological products, growth regulators in combination with macro-and micronutrients [6, 7].

The purpose of the study is to determine the characteristics of the impact of microfertilizers and growth stimulants on the growth, development and formation of productivity of different-growing hybrids of corn LLC «AGROPOSLUGTRANSSERVICE» Chernivtsi region.

Materials and methods of research. Field research was conducted in the field of LLC «AGROPOSLUGTRANSSERVICE» Chernivtsi region, during 2020-2021. The scheme of the experiment provides investigation and interaction of two factors: A - hybrids; B-foliar feeding

Preparation, cultivation of soil for corn in the experiment was carried out in accordance with the recommended technologies for the conditions of the Right Bank Forest-Steppe of Ukraine, in addition to the factors studied.

Sowing was carried out in the third decade of April. Corn hybrid of mediumearly maturity group Zdobutok (FAO 290) and hybrid of medium-ripe group Monika $350 \mathrm{MB}$ (FAO 380) were used for sowing.

Also on the corresponding variants of the experiment, foliar fertilization with complex microfertilizer Nanomix-corn (1,5 l/ ha) in the phase of 7-9 leaves and growth stimulant Emistim C ( $25 \mathrm{ml} / \mathrm{ha})$ in the phase of 5-9 leaves was carried out. The control variant at the experimental site was the variant where no foliar fertilization was carried out.

Hydrothermal conditions in the years of research (2020-2021) were characterized by deviations from the average long-term indicators and did not fully ensure the maximum realization of the genetic potential of the culture. But in general, the soil and climatic conditions of the right-bank Forest-Steppe are favorable for 
growing corn.

The object of research is the processes of growth, development of corn plants and the formation of grain productivity depending on foliar fertilization.

Subject of research - corn hybrids, grain yield, biostimulator of plant growth, microfertilizer.

Research methods: 1) field; 2) laboratory: a) morphological; b) physical; 3) comparative and calculated.

Research results. The results of research show that on average in two years in the conditions of LLC «AGROPOSLUGTRANSSERVICE» Chernivtsi district the leaf area of corn plants changed significantly depending on the phase of their development, foliar fertilization and hybrid composition.

The leaf surface area of corn plants is an important indicator in the formation of productivity as an element of photosynthetic productivity. The further yield of corn grain will depend on this indicator (table 1).

Under control, the leaf surface area of the middle-early hybrid of corn The yield in the phase of 12 leaves was 20,88 thousand $\mathrm{m}^{2} / \mathrm{ha}$. When using foliar fertilization with the drug Nanomix-corn, the leaf surface area of the middle-early hybrid of corn The yield in the phase of 12 leaves increased by 14,85\% and amounted to 23,98 thousand $\mathrm{m}^{2} /$ ha.

And with the combined use of Nanomix-corn + Emistim C in foliar feeding, the leaf surface area of medium-early corn hybrid The yield in the 12-leaf phase increased by $19,92 \%$ relative to control and amounted to 25,04 thousand $\mathrm{m}^{2} / \mathrm{ha}$.

Under control, the leaf surface area of the medium-early corn hybrid Zdobutoku in the flowering phase was 33,27 thousand $\mathrm{m}^{2} / \mathrm{ha}$. When using foliar fertilization with the drug Nanomix-corn, the leaf surface area of the middle-early hybrid of corn The yield in the flowering phase increased by 10,37\% and amounted to 36,72 thousand $\mathrm{m}^{2} / \mathrm{ha}$. And with the combined use of Nanomix-corn + Emistim C in foliar feeding, the leaf surface area of medium-early corn hybrid Yield in the flowering phase increased by $14.09 \%$ relative to control and amounted to 37,96 thousand. $\mathrm{m}^{2} / \mathrm{ha}$.

The control of the leaf surface area of the middle-early hybrid of corn: the yield in the phase of milk ripeness was 33,01 thousand $\mathrm{m}^{2} / \mathrm{ha}$. When using foliar fertilization with Nanomix-corn, the leaf surface area of medium-early corn hybrid The yield in the milk ripeness phase increased by $9,87 \%$ and amounted to 36,27 thousand $\mathrm{m}^{2} / \mathrm{ha}$.

And with the combined use of Nanomix-corn + Emistim C in foliar feeding, the leaf surface area of medium-early corn hybrid The yield in the milk ripeness phase increased by $13,66 \%$ relative to control and amounted to 37,52 thousand $\mathrm{m}^{2} / \mathrm{ha}$.

The control of the leaf surface area of the middle-early hybrid of corn: the yield in the wax ripeness phase was 29,02 thousand $\mathrm{m}^{2} / \mathrm{ha}$. When using foliar fertilization with Nanomix-corn, the leaf surface area of the middle-early corn hybrid The yield in the wax ripeness phase increased by $11,61 \%$ and amounted to 33,39 thousand $\mathrm{m}^{2} / \mathrm{ha}$.

And with the combined use of Nanomix-corn + Emistim C in foliar feeding, the leaf surface area of medium-early corn hybrid The yield in the wax ripening phase increased by 
Table 1

Increasing the leaf surface area of medium-early corn hybrid depending on foliar fertilization, (average for 2020-2021), thousand $\mathrm{m}^{2} / \mathrm{ha}^{*}$

\begin{tabular}{|c|c|c|c|c|c|}
\hline \multirow{2}{*}{$\begin{array}{c}\text { Hybrid } \\
\text { (factor A) }\end{array}$} & \multirow{2}{*}{$\begin{array}{c}\text { Foliar feeding } \\
\text { (factor B) }\end{array}$} & \multicolumn{4}{|c|}{ Phases of plant development } \\
\cline { 3 - 6 } & & 12 leaves & flowering & milk ripeness & wax ripeness \\
\hline \multirow{3}{*}{} & Without processing & 20,88 & 33,27 & 33,01 & 29,02 \\
\cline { 2 - 6 } & Nanomix corn & 23,98 & 36,72 & 36,37 & 32,39 \\
\cline { 2 - 6 } & $\begin{array}{c}\text { Nanomix-corn + } \\
\text { Emistim C }\end{array}$ & 25,04 & 37,96 & 37,52 & 32,92 \\
\hline
\end{tabular}

Note*. Based on our own research.

13,43\% relative to control and amounted to 32,92 thousand $\mathrm{m}^{2} /$ ha (table 2). Under control, the leaf surface area of the medium-ripe hybrid Monica $350 \mathrm{MW}$ in the 12-leaf phase was 22,92 thousand $\mathrm{m}^{2} / \mathrm{ha}$. When using foliar fertilization with the drug Nanomixcorn, the leaf surface area of the medium-ripe hybrid Monica $350 \mathrm{MW}$ in the phase of 12 leaves increased by $10,82 \%$ and amounted to 25,40 thousand $\mathrm{m}^{2} / \mathrm{ha}$. And with the combined use of Nanomix-corn + Emistim C in foliar feeding, the leaf surface area of the medium-ripe hybrid Monica $350 \mathrm{MW}$ in the 12-leaf phase increased by $17,36 \%$ relative to control and amounted to 26,90 thousand $\mathrm{m}^{2} / \mathrm{ha}$.

Table 2

Increasing the leaf surface area of medium-ripe corn hybrid depending on foliar fertilization, (average for $2020-2021$ ), thousand $\mathrm{m}^{2} / \mathrm{ha}$ *

\begin{tabular}{|c|c|c|c|c|c|}
\hline \multirow{2}{*}{$\begin{array}{c}\text { Hybrid } \\
\text { (factor A) }\end{array}$} & \multirow{2}{*}{$\begin{array}{l}\text { Foliar feeding } \\
\text { (factor B) }\end{array}$} & \multicolumn{4}{|c|}{ Phases of plant development } \\
\hline & & 12 leaves & flowering & milk ripeness & waxy ripeness \\
\hline \multirow{3}{*}{ 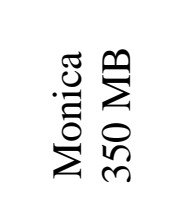 } & Without processing & 22,92 & 38,23 & 36,90 & 32,39 \\
\hline & Nanomix corn & 25,40 & 41,32 & 40,71 & 35,75 \\
\hline & $\begin{array}{l}\text { Nanomix-corn + } \\
\text { Emistim C }\end{array}$ & 26,90 & 42,74 & 41,68 & 37,17 \\
\hline
\end{tabular}

Note*. Based on our own research.

Under control, the leaf surface area of the medium-ripe hybrid Monica $350 \mathrm{MW}$ in the flowering phase was 38,23 thousand $\mathrm{m}^{2} /$ ha. When using foliar fertilization with Nanomix-corn, the leaf surface area of the medium-ripe hybrid Monica 350 MW in the flowering phase increased by $8,08 \%$ and amounted to 41,32 thousand $\mathrm{m}^{2} / \mathrm{ha}$. And with the combined use of Nanomix-corn + Emistim $C$ in foliar feeding, the leaf surface area of the medium-ripe hybrid Monica $350 \mathrm{MW}$ in the flowering phase increased by $11,79 \%$ relative to control and amounted to 42,74 thousand $\mathrm{m}^{2} / \mathrm{ha}$.

Under control, the leaf surface area of the medium-ripe hybrid Monica $350 \mathrm{MW}$ in the phase of milk ripeness was 36,90 thousand $\mathrm{m}^{2} / \mathrm{ha}$. When using foliar fertilization with Nanomix-corn, the leaf surface area of the medium-ripe hybrid Monica $350 \mathrm{MW}$ in the phase of milk ripeness increased by $10,32 \%$ and amounted to 40,71 thousand $\mathrm{m}^{2} / \mathrm{ha}$. And with the combined use of Nanomix-corn + Emistim C in 
foliar feeding, the leaf surface area of the medium-ripe hybrid Monica $350 \mathrm{MW}$ in the phase of milk ripeness increased by 12,95\% relative to control and amounted to 41,68 thousand $\mathrm{m}^{2} /$ ha.

Under the control, the leaf surface area of the medium-ripe hybrid Monica 350 MW in the wax maturity phase was 32,39 thousand $\mathrm{m}^{2} / \mathrm{ha}$. When applying foliar fertilization with the drug Nanomix-corn, the leaf surface area of the medium-ripe hybrid Monica 350 MW in the wax phase increased by $10,37 \%$ and amounted to 35,75 thousand $\mathrm{m}^{2} / \mathrm{ha}$. And with the combined use of Nanomix-corn + Emistim $\mathrm{C}$ in foliar feeding, the leaf surface area of the medium-ripe hybrid Monica $350 \mathrm{MW}$ in the wax ripeness phase increased by 14,75\% relative to control and amounted to 37,17 thousand $\mathrm{m}^{2} / \mathrm{ha}$. Due to the use of foliar fertilization Nanomix-corn + Emistim C significantly increases the total leaf surface area for all hybrids of different maturity groups, and at the beginning of the milk ripening phase there is a general pattern of leaf surface reduction in all variants of the experiment.

Conclusions. Thus, the highest indicator of leaf surface showed medium-ripe hybrid Monica 350 MW for treatment of vegetative plants with microfertilizer Nanomix - corn and plant growth stimulant Emistim C and it amounted to 42,74 thousand $\mathrm{m}^{2} /$ ha in the flowering phase. The use of a complex of the above fertilizers has led to an increase in leaf surface area in all phases of plant development in all studied hybrids.

\section{Список використаної літератури}

1. Kolisnyk O., Khodanitska O., Butenko A., Lebedieva N., Yakovets L., Tkachenko O., Ihnatieva O., Kurinnyi O. Influence of foliar feeding on the grain productivity of corn hybrids in the conditions of the Right-bank forest-steppe of Ukraine. Ukrainian Journal of Ecology. 2020. 10 (2). P. 40-44.

2. Mazur V. Kolisnyk O., Yakovets L. Dialial analysis of the combination capacity of resistance to diseases and pests of the source selection corn material. Сільське господарство та лісівництво. 2021. №21. Р. 233-244.

3. Яковець Л.А. Зміна вмісту важких металів при досушці зерна кукурудзи. Сільське господарство та лісівнищтво. 2018. №. 11. С. 152-161.

4. Мазур В.А., Паламарчук В.Д., Поліщук I.C., Паламарчук О.Д. Новітнітагротехнології у рослинництві: Підручник. Вінниця. 2017. 588 с.

5. Мазур В. А., Циганська О.І., Шевченко Н. В. Висота рослин кукурудзи залежно від технологічних прийомів вирощування. Сільське господарство та лісівництво. 2018. Вип. 8. С. 5-13.

6. Мазур В. А., Шевченко Н. В. Формування площі листкової поверхні рослин гібридів кукурудзи залежно від технологічних прийомів вирощування. Біоресурси і природокористування. Київ. 2018. Т. 10. № 1, 2. С. 108-114.

7. Шевченко Н. В. Урожайність зерна кукурудзи залежно від обробки насіння та позакореневих підживлень. Наукові доповіді НУБіП України: 2018. Вип. 3 (73). URL: http://journals.nubip.edu.ua/index.php /Dopovidi/article /view/10820/9463. 


\section{Список використаної літератури у транслітерації / References}

1. Kolisnyk O., Khodanyts'ka O., Butenko A., Lebedyeva N., Yakovets' L., Tkachenko O., Ihnat'yeva O., Kurinnyy O. (2020). Vplyv pozakorenevoho pidzhyvlennya na zernovu produktyvnist' hibrydiv kukurudzy $\mathrm{v}$ umovakh Pravoberezhnoho Lisostepu Ukrayiny [Ihnatieva, O. Kurinnyi. Influence of foliar feeding on the grain productivity of corn hybrids in the conditions of the Right-bank forest-steppe of Ukraine]. Ukrayins'kyy ekolohichnyy zhurnal. - Ukrainian Journal of Ecology.10 (2). 40-44. [in Ukrainian].

2. Mazur V. Kolisnyk O., Yakovets L. (2021). Tsyfrovyy analiz kombinatsiynoyi zdatnosti stiykosti do khvorob i shkidnykiv vykhidnoho selektsiynoho kukurudzyanoho materialu [Dialial analysis of the combination capacity of resistance to diseases and pests of the source selection corn material]. Sil`s `ke gospodarstvo ta lisivny`cztvo - Agriculture and forestry. №21. 233-244 [in Ukrainian].

3. Yakovets' L.A. (2018) Zmina vmistu vazhkykh metaliv pry dosushtsi zerna kukurudzy [Changes in the content of heavy metals during drying of corn grain. Agriculture and forestry]. Sil's 'ke gospodarstvo ta lisivny 'cztvo - Agriculture and forestry. № 11. 152-161. [in Ukrainian].

4. Mazur V.A., Palamarchuk V.D., Polishchuk I.S., Palamarchuk O.D. (2017). Novitnitahrotekhnolohiyi u roslynnytstvi [The latest agricultural technologies in crop production]. [in Ukrainian].

5. Mazur V. A., Tsyhans'ka O.I., Shevchenko N. V. (2018). Vysota roslyn kukurudzy zalezhno vid tekhnolohichnykh pryyomiv vyroshchuvannya [Height of corn plants depending on technological methods of cultivation]. Sil's'ke gospodarstvo ta lisivny`cztvo - Agriculture and forestry. № 8. 5-13. [in Ukrainian].

6. Mazur V. A., Shevchenko N. V. (2018). Formuvannya ploshchi lystkovoyi poverkhni roslyn hibrydiv kukurudzy zalezhno vid tekhnolohichnykh pryyomiv vyroshchuvannya [Formation of leaf surface area of maize hybrids depending on technological methods of cultivation]. Bioresursy i pryrodokorystuvannya Bioresources and nature management. Vols. 10. № 1, 2. 108-114. [in Ukrainian].

7. Shevchenko N. V. (2018). Urozhaynist' zerna kukurudzy zalezhno vid obrobky nasinnya ta pozakorenevykh pidzhyvlen' [Maize grain yield depending on seed treatment and foliar fertilization]. Naukovi dopovidi NUBiP Ukrayiny: Issue. 3 (73). URL: http://journals.nubip.edu.ua/index.php/Dopovidi/article/view/10820/9463.

\section{АНОТАЦІЯ \\ ВПЛИВ ТЕХНОЛОГІЧНИХ ПРИЙОМІВ ВИРОЩУВАННЯ НА ПЛОЩУ ЛИСТКОВОЇ ПОВЕРХНІ РОСЛИН КУКУРУДЗИ}

У статті наведено результати досліджень впливу позакореневих підживлень мікродобривами та стимуляторами росту на формування площі листкової поверхні гібридів кукурудзи, як основної складової фотосинтетичного потенціалу рослин та їх продуктивності в цілому. Одним із сучасних напрямів підвищення урожайності та якості 
продукиії рослинництва $\epsilon$ впровадження у сільськогосподарське виробництво енергозберігаючих технологій із застосуванням регуляторів росту рослин та мікродобрив.

Використання їх для передпосівної обробки насіння забезпечує інтенсивний ріст $i$ розвиток рослин, високу польову схожість, а обприскування рослин під час вегетачії сприяє процесам росту $i$ розвитку рослин, підвищенню стійкості їх до несприятливих погодних умов, хвороб, підвищенню врожайності. Зважаючи на це, регулятори росту та мікродобрива все більше стають невід'ємними елементами інтенсивних технологій вирощування сільськогосподарських культур. Крім того забезпечення продуктивності рослин, та оптимальної площуі листкової поверхні, можливо досягти не лише застосуванням одного стимулятора росту, чи мікродобрива, а саме їх комплексом. Тому актуальним $\epsilon$ дослідження використання саме комплексу стимулятора росту рослин та мікродобрива. Що в свою чергу забезпечить реалізацію біологічного потенціалу рослин кукурудзи, та зниження витрат на одиницю вирощеної продукиії.

Згідно програми наших досліджень ми вивчали вплив мікродобрив та стимуляторів росту на ріст, розвиток та формування асиміляційної поверхні гібридів кукурудзи різних груп стиглості. За результатами досліджень встановлено, щэо найвищий показник площі листкової поверхні було зафіксовано у середньостиглого гібриду Моніка 350 МВ, 42,74 тис. $\mathrm{M}^{2} / 2 а$ за використання позакореневого підживлення у фазу 5-9 листків комплексом мікродобрива Наномікс-кукурудза та стимулятора росту Емістим С. Площа листкової поверхні у середньораннього гібриду Здобуток 37,96 тис. $\mathrm{M}^{2} / 2 а$, також була зафіксовання за використання даного комплесу. Також використання лише мікродобрива Наномікскукурудза, призвело до зростання показника площуі листкової по всіх досліджуваних гібридах.

Ключові слова: кукурудза, гібрид, листкова поверхня, мікродобриво, біостимулятори.

Табл. 2. Літ. 7.

\section{АННОТАЦИЯ \\ ВЛИЯНИЕ ТЕХНОЛОГИЧЕСКИХ ПРИЕМОВ ВЫРАЩИВАНИЯ НА ПЛОЩАДЬ ЛИСТОВОЙ ПОВЕРХНОСТИ РАСТЕНИЙ КУКУРУЗЫ}

В статье представлены результаты исследований влияния внекорневых подкормок микроудобрениями и стимуляторами роста на формирование площзади листовой поверхности гибридов кукурузы, как основной составляющей фотосинтетического потенциала растений и их продуктивности в целом.

Одним из современных направлений повыщения урожайности и качества продукиии растениеводства есть внедрение в сельскохозяйственное производство энергосберегающих технологий с применением регуляторов роста растений и микроудобрений.

Использование их для предпосевной обработки семян обеспечивает интенсивный рост и развитие растений, высокую полевую всхожесть, а опрыскивание растений во время вегетации способствует проиессам роста и развития растений, повышению устойчивости к неблагоприятным погодным условиям, болезням, повышению урожайности. В связи с этим регуляторы роста и микроудобрения все больше становятся неотьемлемыми элементами интенсивных технологий вырашивания сельскохозяйственных культур. Кроме того, обеспечение продуктивности растений и оптимальной площади листовой поверхности можно достичь не только применением одного стимулятора роста или микроудобрения, а именно их комплексом. Поэтому актуально исследование использования именно комплекса стимулятора роста растений и микроудобрения. Что в свою очередь обеспечит реализацию биологического потенциила растений кукурузы и снижение затрат на единицу выращенной продукиии.

Согласно программе наших исследований, мы изучали влияние микроудобрений $и$ стимуляторов роста на рост, развитие и формирование ассимиляционной поверхности гибридов кукурузы разных групп спелости. По результатам исследований установлено, что самый високий показатель площуади листовой поверхности был зафиксирован у 
среднеспелого гибрида Моника 350 МB, 42,74 mыс. м $^{2} / 2 а$ при использовании внекорневой подкормки в фазу 5-9 листьев комплексом микроудобрения Наномикс-кукуруза и стимулятора роста Эмистим С. Площуад листовой поверхности у среднераннего гибрида Здобуток 37,96 тыс. м²/га, также была зафиксирована при использовании данного комплеса. Также использование только микроудобрения Наномикс-кукуруза привело к росту показателя площуади листовой по всем исследуемым гибридам.

Ключевые слова: гибрид, биостимулятор, микроудобрение, кукуруза, площадь листовой поверхности, группы спелости.

Табл. 2. Лит. 7.

\section{Інформація про авторів}

Шевченко Наталія Василівна - кандидат сільськогосподарських наук, старший викладач кафедри рослинництва, селекції та біоенергетичних культур Вінницького національного аграрного університету, (21008, м. Вінниця, вул. Сонячна, 3. e.mail: nataliashevchenko111@gmail.com).

Яковець Людмила Анатоліївна - кандидат сільськогосподарських наук, старший викладач кафедри ботаніки, генетики та захисту рослин Вінницького національного аграрного університету, (21008, м. Вінниця, вул. Сонячна, 3. e.mail: ludmila28334@gmail.com).

Шевченко Наталия Васильевна - кандидат сельскохозяйственных наук, старший преподаватель кафедры растениеводства, селекции и биоэнергетических культур, Винницкого национального аграрного университета, (21008, г. Винница, ул. Солнечная, 3 e.mail: nataliashevchenko111@gmail.com).

Яковец Людмила Анатольевна - кандидат сельскохозяйственных наук, старший преподаватель кафедры ботаники, генетики и защиты растений Винницкого национального аграрного университета, (21008, г. Винница, ул. Солнечная, 3 e.mail: ludmila28334@gmail.com).

Shevchenko Natalia - Candidate of Agricultural Sciences, Senior Lecturer of the Department of Plant Production, Selection and Bioenergetic Cultures of Vinnytsia National Agrarian University, (21008, Vinnytsia, Soniachna Str. 3, e.mail: nataliashevchenko111@gmail.com).

Yakovets Liudmyla - Candidate of Agricultural Sciences, Senior Lecturer of Department of Botany, Genetics and Plant Protection of Vinnytsia National Agrarian University, (21008, Vinnytsia, Soniachna Str. 3, e.mail: ludmila28334@gmail.com). 